\title{
The Influence of Budgeting System, Organizational Culture, and Firm Size to Performance
}

\author{
By: \\ Mochamad Muslih \\ Email: mochamadmuslih@stietribhakti.ac.id
}

Tri Bhakti Business School

\begin{abstract}
Abstrak
Terdapat ketidakkonsistenan dalam hasil penelitian sebelumnya mengenai dampak anggaran terhadap kinerja. Beberapa penelitian menyimpulkan bahwa proses penganggaran memiliki dampak signifikan terhadap kinerja, tetapi beberapa studi tidak. Tujuan penelitian ini adalah untuk mengetahui pengaruh sistem penganggaran terhadap kinerja. Penelitian ini menggunakan metode penelitian kuantitatif. Budaya organisasi dan ukuran perusahaan ditambahkan sebagai variabel kontrol. Populasi dalam penelitian ini adalah perusahaan yang terdaftar di Bursa Efek Indonesia yang diklasifikasikan sebagai LQ45. Sampel penelitian adalah perusahaan yang tergolong LQ45 yang diambil secara acak.

Hasil penelitian menunjukkan proses penganggaran memiliki pengaruh yang signifikan terhadap kinerja perusahaan tetapi dengan tanda yang berbeda. Artinya proses penganggaran memberikan efek negatif terhadap kinerja perusahaan. Budaya organisasi dan ukuran perusahaan berpengaruh positif dan signifikan terhadap kinerja perusahaan.
\end{abstract}

Kata kunci: Kinerja, penganggaran, budaya, ukuran.

\begin{abstract}
There are inconsistencies in past research results regarding the impact of budgets on performance. Some studies concluded that budgeting process had significant effect on performance, but some studies didn't. The purpose of this study is to determine the influence of budgeting system on performance.

This research used quantitative research method. Organizational culture and firm size are added as control variables. The population of this research are companies listed at Bursa Efek Indonesia classified as LQ45. The samples of research are companies classified as LQ45 taken randomly.

The results showed the budgeting process has significant effect on firm performance but with different sign. It means that budgeting process gives negative effect to firm performance. Organizational culture and firm size have significant positive effect on firm performance.
\end{abstract}

Keywords: Performance, budgeting, culture, size.

\section{A. Pendahuluan}

Proses penganggaran merupakan salah satu bagian dari tahapan sistem pengendalian manajemen, yang bertujuan untuk meningkatkan kinerja perusahaan. Dalam penganggaran ditetapkan rencana penerimaan, pengeluaran, dan pembiayaan perusahaan periode berikutnya. Empat tujuan dasar penyiapan anggaran adalah unntuk menyelaraskan perencanaan strategis, untuk membantu mengkoordinasikan berbagai kegiatan dari beberapa bagian, untuk memberikan wewenang kepada para manajer dalam melakukan pengeluaran yang telah disetujui, untuk memberitahukan manajemen mengenai rencana kinerjanya, dan untuk memperoleh komitmen yang menjadi dasar 
bagi pimpinan ketika melakukan evaluasi kinerja nyata setelah perencanaan dan anggaran dilaksanakan. Pendekatan penyusunan anggaran yang terbaik adalah berdasarkan PPBS (Planning Programming Budgeting System). Dalam PPBS anggaran disusun berdasarkan perencanaan strategis yang telah ditetapkan perusahaan sehingga semua rencana penerimaan dan pengeluaran telah memiliki output dan outcome tertentu bahkan sampai benefit dan impact. Proses penganggaran membutuhkan banyak sumber daya perusahaan. Namun apakah proses ini akan memberikan dampak yang signifikan pada peningkatan kinerja perusahaan. Banyak perusahaan yang melaksanakan proses penganggaran namun rentabilitasnya rendah.

Terdapat berbagai penelitian mengenai pengaruh penganggaran untuk meningkatkan kinerja perusahaan. Mei, Ming dan Kuo (2009) dari penelitiannya menyimpulkan bahwa informasi dari sistem informasi berdampak positif terhadap kinerja inovasi bila kekurangan anggaran rendah dan tidak berdampak sama sekali bila kekurangan anggaran tinggi. Jeremias dan Yigit (2013) menunjukan hasil penelitian yang memperkuat bahwa pengaruh partisipasi penganggaran terhadap komitmen tujuan positif dan signifikan dan pengaruh komitmen tujuan terhadap kinerja positif dan signifikan. Johanson dan Siverbo (2014) juga menyimpulkan bahwa bila kekacauan anggaran sangat besar maka penggunaan anggaran yang ketat akan meningkatkan kemungkinan memenuhi target-target yang telah ditetapkan. Namun Macinatti dan rizo (2014) menyimpulkan dari hasil penelitiannya bahwa tidak ada hubungan langsung partisipasi penganggaran dengan kinerja. Hubungan keduanya harus di mediasi oleh komitmen tujuan penganggaran. Lidia (2015) memberikan simpulan yang positif bahwa anggaran merupakan alat yang berguna dalam aktivitas ekonomi dan mendukung kinerja prima. Giuberti (2015) juga menunjukan dari penelitiannya bahwa Lembaga Penganggaran Pemerintah federal berhasil menurunkan defisit pemerintahan federal Brazil dengan menggunakan penganggaran. Arnold dan Gillenkirch (2015) dalam penelitiannya menghasilkan simpulan yang lebih positif mengenai penggunaan anggaran untuk perencanaan dan sekaligus untuk evaluasi kinerja. Namun dalam penelitian terkini yang dilakukan oleh Messer (2017) menyimpulkan bahwa isi anggaran dianggap cuma kebohongan.

Dengan demikian masih terdapat ketidakkonsistenan hasil-hasil penelitian terdahulu mengenai pengaruh penganggaran terhadap kinerja perusahaan. Karena itu penelitian ini dilakukan untuk melihat lebih jauh seberapa besar kontribusi penganggaran terhadap kinerja perusahaan.

Budaya perusahaan merupakan salah satu pendorong kinerja perusahaan. Telah banyak penelitian terdahulu mengenai pengaruh budaya organisasi terhadap kinerja perusahaan. Idris, Wahab dan 
Jaapar (2015) menyimpulkan dalam hasil penelitiannya bahwa integrasi budaya organisasi merupakan aktivitas yang sangat penting dalam suatu kegiatan merger dan akuisisi. Budaya organisasi berpengaruh terhadap kinerja perusahaan. Namun seringkali dalam suatu kegiatan merger dan akuisisi, tidak terbentuk integrasi budaya yang baik antar 2 (dua) atau lebih perusahaan karena tidak dikelola dengan baik. Altindag dan Kosedagi (2015) juga menyimpulkan dalam hasil penelitiannya bahwa terdapat hubungan yang bermakna antara kecerdasan emosi, budaya lembaga inovatif, dan kinerja karyawan. Imam Syafii et al (2015) melakukan penelitian mengenai peranan budaya perusahaan dan motivasi pegawai sebagai variabel pemediasi gaya kepemimpinan yang mempengaruhi kinerja pegawai.

Ukuran perusahaan (firm size) merupakan tingkat atau ukuran besarnya perusahaan. Indikator ukuran perusahaan dapat dijabarkan dalam berbagai ukuran seperti misalnya nilai aset dan jumlah modal. Berbagai penelitian telah membuktikan adanya hubungan antara ukuran perusahaan dengan laba perusahaan. Alexander et. al (2005) menyimpulkan dari hasil penelitiannya bahwa ada hubungan yang positif antara ukuran perusahaan dengan struktur modal. Amato et al (2007) juga menyimpulkan bahwa terdapat hubungan yang positif antara ukuran perusahaan dengan laba perusahaan. Gaur (2007) menyatakan dalam hasil penelitiannya bahwa ukuran perusahaan berpengaruh pada tingkat persediaan dan pertumbuhan penjualan. Mesut Dogan ( 2013) juga menyimpulkan bahwa terdapat hubungan positif antara indikator-indikator ukuran dengan profitabilitas perusahaan. Jadi bila ukuran perusahaan meningkat maka kinerja juga akan meningkat. Chang et. al (2013) menunjukan dari hasil studi empirisnya bahwa terdapat hubungan antara ukuran perusahaan dengan kinerja keuangan. Abiodun (2013) menyimpulkan dalam hasil penelitiannya bahwa terdapat hubungan positif antara ukuran perusahaan terhadap profitabilitas perusahaan pabrikasi di Nigeria. Kumas et. al (2014 juga menyimpulkan bahwa terdapat hubungan antara ukuran perusahaan dengan kualifikasi pekerjaan. Ruang lingkup penelitian ini adalah mengenai pengaruh penganggaran, budaya organisasi, dan ukuran perusahaan terhadap kinerja perusahaan. Berdasarkan pembahasan latar belakang penelitian tersebut di atas, pertanyaan penelitiannya apakah penganggaran mempengaruhi kinerja perusahaan, apakah budaya organisasi mempengaruhi kinerja perusahaan, dan apakah ukuran perusahaan mempengaruhi kinerja perusahaan. 
Tujuan penelitian dalam penelitian ini adalah untuk mengetahui adanya pengaruh penganggaran terhadap kinerja perusahaan, adanya pengaruh budaya organisasi terhadap kinerja perusahaan, dan adanya pengaruh ukuran perusahaan terhadap kinerja perusahaan.

\section{B. Tinjauan Teoritis}

Grand theory dari penelitian ini adalah agency theory. Pada dasarnya agency theory mengatur tentang hubungan antara pemilik dengan manajer. Hubungan antara pemilik dan manajer harus di atur sehingga manajer akan memutuskan dan bertindak untuk kepentingan pemilik atau pemegang saham. Jensen and Meckling (1976) mengatakan bahwa pemegang saham dapat meyakinkan bahwa manajer sebagai agen mengambil keputusan-keputusan yang optimal hanya bila insentif yang layak diberikan kepada para manajer dan dilakukan pemantauan secara layak kepada para manajer. Bonazzi dan Islam (2007) juga mengatakan bahwa manajer mungkin tidak selalu bertindak untuk kepentingan terbaik pemegang saham bila pengendalian atas perusahaan terpisah dari kepemilikannya. Salah satu bentuk dari pengendalian yang dilakukan oleh pemilik adalah pengendalian melalui penganggaran (budgetary control).

Kinerja perusahaan merupakan tujuan dari semua entitas bisnis. Kinerja perusahaan merupakan hasil dari kegiatan manajemen. Parameter yang sering digunakan untuk menilai kinerja suatu perusahaan yang dilakukan dengan menggunakan pendekatan di mana informasi keuangan diambil dari laporan keuangan atau laporan keuangan lainnya. Terdapat beberapa pengertian kinerja. Menurut Verbonchu (Verboncu, 2005 dalam Lidia, 2015) kinerja merupakan tingkat tertentu dari hasil terbaik yang diperoleh dan melibatkan pencapaian tujuan entitas (Verboncu, 2005 dalam Lidia, 2015). Jadi berkinerja berarti mencapai tujuan-tujuan perusahaan yang telah ditetapkan. Messer (2017) menyatakan dalam hasil penelitiannya bahwa membandingkan kinerja aktual dengan kegiatan yang direncanakan merupakan kontrol manajemen yang penting. Implikasi dari pernyataan Messer tersebut adalah bahwa kinerja merupakan apa yang nyatanya telah dilakukan. Dincer, Hacioglu, dan Yuksel (2017) menyatakan bahwa pengukuran kinerja adalah proses yang menganalisis keluaran perusahaan dan efektivitas sumber daya yang diperoleh oleh perusahaan ini. Menganalisis disini dapat berupa membandingkan dengan target, capaian tahun lalu, atau dengan industri sejenis. Kask dan Linton (2016) membagi performance atas beberapa tingkatan yaitu no performance, low performance, medium performance, dan high performance. Kriteria dari tingkatan-tingkatan kinerja tersebut harus ditetapkan oleh perusahaan. 
Penilaian kinerja bertujuan untuk menentukan efektivitas operasi perusahaan yang telah dilakukan. Kinerja non-keuangan, mengukur kinerja dengan menggunakan satuan pengukuran non-keuangan seperti kepuasan pelanggan dan kepuasan pegawai. Sebaliknya kinerja keuangan menggunakan satuan pengukuran yang bersifat keuangan seperti laba tahun berjalan, return on asset, return on equity, dan sebagainya. Proxy kinerja perusahaan yang akan digunakan dalam penelitian ini adalah laba perusahaan. Laba perusahaan yang digunakan adalah laba tahun berjalan yang diambil dari laporan keuangan perusahaan.

Sistem Pengendalian Manajemen (SPM) merupakan bangunan besar manajemen yang dimaksudkan untuk menggerakan seluruh usaha-usaha perusahaan dan mengendalikannya dengan tujuan untuk mencapai sasaran-sasaran yang telah ditetapkan. Untuk dapat berfungsi sebagai sistem yang mampu mencapai tujuan perusahaan, maka sistem pengendalian manajemen harus memiliki perangkat yang utamanya terdiri atas instrumen yang mengukur pencapaian suatu kegiatan (detector), instrumen yang melakukan pembandingan antara realisasi dengan standar (assessor), dan instrumen yang melakukan tindak lanjut terhadap kesenjangan yang ditemukan dalam pemantauan (efektor). Komponen utama dari suatu sistem pengendalian manajemen adalah perencanaan strategis, penganggaran, pemantauan pelaksanaan, dan tindaklanjut terhadap kesenjangan (gap/variance) yang terjadi dalam pelaksanaan. Manajer seharusnya berusaha untuk meminimalkan kesenjangan dalam pelaksanaan anggaran bila manajer bekerja untuk kepentingan terbaik perusahaan. Semakin kecil kesenjangan yang terjadi maka akan semakin besar kemungkinan tujuan-tujuan perusahaan akan tercapai.

Penganggaran merupakan salah satu bagian dari tahapan sistem pengendalian manajemen. Empat tujuan dasar penyiapan anggaran adalah untuk menyelaraskan perencanaan strategis, untuk membantu mengkoordinasikan berbagai kegiatan dari beberapa bagian, dan untuk memberikan wewenang kepada para manajer dalam melakukan pengeluaran yang telah disetujui, untuk memberitahukan manajemen mengenai rencana kinerjanya, dan untuk memperoleh komitmen yang menjadi dasar bagi pimpinan ketika melakukan evaluasi kinerja nyatanya.

Terdapat 4 (empat) pendekatan dalam penyusunan anggaran yaitu pendekatan tradisional; pendekatan kinerja; planning, programming, and budgeting system (PPBS), dan anggaran berbasis nol (ZBB). Pendekatan tradisional adalah yang paling sederhana, terdiri atas penerimaan dan pengeluaran saja. Pendekatan selanjutnya adalah pendekatan berbasis kinerja. Pendekatan ini lebih maju dari pendekatan tradisional karena dalam pendekatan ini rencana pembiayaan sudah 
dikaitkan dengan output yang akan diperoleh. Pendekatan lainnya adalah pendekatan berbasis 0 (zero based budgeting). Dengan pendekatan anggaran berbasis 0 maka penyusunan anggaran setiap periode dimulai dari awal, dan dianggap tidak ada hubungannya dengan anggaran periodeperiode sebelumnya. Planning Programming Budgeting System (PPBS) adalah pendekatan penyusunan anggaran yang terbaik. Dalam pendekatan PPBS penyusunan anggaran didasarkan pada output dan outcome pada sasaran-sasaran dan tujuan pada perencanaan strategis yang telah ditetapkan perusahaan. Dalam sistem PPBS setiap item pada anggaran yang ditetapkan telah dikaitkan dengan penetapan kinerja pada perencanaan strategis. Dalam penelitian ini dianggap telah terdapat proses penganggaran yang baik bila penyusunan anggaran telah menggunakan PPBS.

Anggaran dapat menjadi alat motivasi bagi perusahaan. Anggaran yang baik akan dapat memotivasi para manajer dan pegawai untuk bekerja secara ekonomis, efektif, dan efisien dalam mencapai target dan tujuan organisasi yang telah ditetapkan. Untuk dapat memotivasi pegawainya anggaran harus menantang tetapi dapat dicapai (challenging but attainable). Jadi anggaran memang harus menantang, tetapi angka-angkanya harus realistis sehingga dapat dicapai. Penyusunan anggaran berbasis PPBS didasarkan pada perencanaan strategis yang penyusunannya telah dilakukan bersama dengan seluruh stakeholders perusahaan sehingga anggaran yang dihasilkan juga telah merupakan hasil dari seluruh stakeholders perusahaan. Perencanaan strategis yang telah ditetapkan menjadi dasar dalam penyusunan anggaran. Pelaksanaan anggaran di evaluasi dan menjadi informasi mengenai pelaksanaan, anggaran, dan perencanaan strategis.

Terdapat berbagai penelitian mengenai pengaruh penganggaran untuk meningkatkan kinerja perusahaan. Mei, Ming dan Kuo (2009) melakukan penelitian mengenai pengaruh informasi dari Sistem Informasi dan kekurangan anggaran terhadap kinerja inovasi. Hasil penelitian menunjukan bahwa informasi dari sistem informasi berdampak positif terhadap kinerja inovasi bila kekurangan anggaran atau defisit anggaran rendah, dan informasi dari sistem informasi tidak berdampak sama sekali bila kekurangan atau defisit anggaran tinggi. Jeremias dan Yigit (2013) melakukan penelitian mengenai variabel pendahulu (information asymmetri), variabel pemediasi (goal commitment dan role ambiguty), dan outcome variable (performance dan job satisfaction) dari budgetary participation di Turkey. Penelitiannya menunjukan hasil yang memperkuat penelitian terdahulu bahwa pengaruh partisipasi penganggaran terhadap komitmen tujuan 
hasilnya positif dan signifikan dan pengaruh komitmen tujuan terhadap kinerja hasilnya positif dan signifikan. Johanson dan Siverbo (2014) melakukan penelitian mengenai penerapan kebijakan pengendalian yang ketat pada organisasi publik yang mengalami kekacauan anggaran. Dia juga menyimpulkan bahwa bila kekacauan anggaran sangat besar maka penggunaan anggaran yang ketat akan meningkatkan kemungkinan memenuhi target-target yang telah ditetapkan. Namun bila kekacauai anggaran tidak besar, maka pengeluaran dapat dilakukan dengan berdasarkan data-data pengeluaran tahun lalu dan arahan dari sistem pengendalian yang ketat tidak ada gunanya. Namun Macinatti dan rizo (2014) menyimpulkan dalam penelitiannya mengenai pengaruh komitmen tujuan penganggaran terhadap kinerja bahwa partisipasi anggaran tidak secara langsung mempengaruhi penggunaan informasi anggaran, tetapi yang terakhir didorong oleh tingkat komitmen tujuan anggaran. Jadi dari hasil penelitian Macinatti dan rizo menunjukan tidak adanya hubungan langsung partisipasi penganggaran dengan kinerja. Hubungannya di mediasi oleh komitmen tujuan penganggaran. Adanya komitmen pada tujuan penganggaran akan meningkatkan kinerja. Lidia (2015) melakukan penelitian mengenai adanya hubungan antara penganggaran dengan kinerja dalam satuan ekonomi. Penelitian Lidia bertujuan untuk menunjukan penggunaan anggaran untuk mendorong peningkatan kinerja pada satuansatuan ekonomi di negara Rumania. Penelitiannya menunjukan hasil yang lebih positif yaitu walaupun anggaran hanya menyumbang $27 \%$ dalam peningkatan kinerja, namun disimpulkan dan diyakini bahwa anggaran merupakan alat yang berguna dalam aktivitas ekonomi dan mendukung kinerja prima. Kinerja merupakan sarana untuk dapat bertahan bagi perusahaan. Penganggaran merupakan salah satu proses yang mendukung kinerja sehingga merupakan aktivitas penting bagi perusahaan. Bahkan Lidia menyatakan bahwa anggaran berguna untuk memotivasi pegawai dan kepemimpinan. Dengan anggaran dapat diterapkan pengendalian yang efektif.

Giuberti (2015) melakukan penelitian mengenai pengaruh lembaga penganggaran pemerintah federal terhadap defisit pemerintah federal. Dari hasil penelitiannya tersebut Giuberti juga menunjukan bahwa Lembaga Penganggaran Pemerintah federal berhasil menurunkan defisit pemerintahan federal Brazil dengan sistem penganggaran yang dilakukannya. Arnold dan Gillenkirch (2015) dalam penelitiannya menghasilkan simpulan yang positif mengenai penggunaan anggaran untuk perencanaan dan sekaligus untuk evaluasi kinerja mengatakan bahwa pembatasan dari atasan untuk membuat anggaran tunggal untuk perencanaan dan evaluasi 
kinerja akan meningkatkan kerjasama bawahan lebih jauh". Jadi penggunaan anggaran tunggal meningkatkan kerjasama atau partisipasi bawahan. Ada beberapa pendapat yang menyarankan digunakannya beberapa jenis anggaran (multiple budget). Lebih lanjut Arnold dan Gillenkirch (2015) mengatakan dalam hasil penelitiannya tentang penggunaan anggaran tunggal bahwa bukti ini dapat membantu menjelaskan ketidakkonsistenan antara saran-saran teoritis untuk menggunakan banyak anggaran untuk banyak tugas dan pengamatan empiris bahwa perusahaan jarang melakukan ini. Namun dalam penelitiannya yang terkini, Messer (2017) menyimpulkan bahwa anggaran dianggap oleh banyak orang sebagai kejahatan yang diperlukan. Dalam organisasi, anggaran digunakan untuk mengalokasikan sumber daya keuangan kepada individu yang ditugasi mengelola dana. Lebih lanjut Messer mengatakan bahwa karena anggaran hanya merupakan dugaan terbaik tentang masa depan, hasil ini menunjukkan bahwa pengeluaran yang direncanakan dimaksudkan untuk mengelola ketidakpastian. Dengan kata lain, karena anggaran itu sengaja disalah artikan, maka dianggap cuma kebohongan.

Dengan demikian masih terdapat inkonsistensi dari hasil penelitian terdahulu mengenai pengaruh anggaran terhadap kinerja perusahaan. Namun lebih banyak penelitian yang menyimpulkan bahwa penganggaran berpengaruh positif pada kinerja perusahaan.

Berdasarkan pembahasan di atas hipotesa penelitiannya adalah:

H1: Penganggaran berpengaruh positif pada kinerja perusahaan

Budaya Organisasi merupakan norma-norma, kepercayaan, atau persepsi bersama yang dianut oleh seluruh insan perusahaan. Indikator utama budaya perusahaan adalah inisiatif individu, tanggung jawab, integritas, dukungan manajemen, kontrol, sistem imbalan, toleransi, dan pola komunikasi.

Budaya perusahaan merupakan salah satu pendorong kinerja perusahaan. Telah banyak penelitian terdahulu mengenai pengaruh budaya organisasi terhadap kinerja perusahaan. Idris, Wahab dan Jaapar (2015) melakukan penelitian mengenai pengaruh integrasi budaya perusahaan dalam kegiatan merger dan akuisisi perusahaan terhadap kinerja organisasi. Dalam hasil penelitiannya Wahab dan Jaapar menyebutkan bahwa integrasi budaya organisasi merupakan aktivitas yang sangat penting dalam suatu kegiatan merger dan akuisisi. Budaya organisasi berpengaruh terhadap kinerja perusahaan. Namun seringkali dalam suatu kegiatan merger dan akuisisi, tidak terbentuk integrasi budaya yang baik antar 2 (dua) atau lebih perusahaan karena tidak dikelola dengan baik. Altindag dan Kosedagi (2015) melakukan penelitian mengenai hubungan antara 
intelejensia manajer, budaya organisasi yang inovatif, dan kinerja pegawai. Tujuan penelitian ini adalah untuk menekankan pentingnya menyusun budaya institusi yang inovatif dalam suatu perusahaan dan memiliki manajer yang memiliki emotional intelligence yang tinggi. Hasil penelitiannya menunjukan bahwa budaya organisasi dan intelejensi emosional berpengaruh pada kinerja perusahaan. Imam Syafii et al (2015) melakukan penelitian mengenai peranan budaya perusahaan dan motivasi pegawai sebagai variabel pemediasi gaya kepemimpinan yang berhubungan dengan kinerja pegawai. Hasil penelitiannya menunjukan bahwa terdapat 3 (tiga) variabel yang mempengaruhi kepuasan pegawai yaitu gaya kepemimpinan, budaya perusahaan, dan kepuasan pegawai.

Chen, Podolski, dan Veeraraghavan (2017) melakukan penelitian dalam skala yang lebih luas, yaitu mengenai pengaruh budaya nasional terhadap inovasi perusahaan. Dalam penelitian ini dipelajari bagaimana norma-norma budaya sepanjang dimensi individualisme dan kolektivisme dan uncertainty avoidance mempengaruhi inovasi perusahaan. Simpulan dari penelitian ini juga menunjukan bahwa budaya nasional suatu bangsa atau negara memainkan peranan yang penting untuk mempengaruhi inovasi perusahaan. Selanjutnya menurut Chen, Podolski, dan Veeraraghavan (2017), Perusahaan yang terletak di negara-negara yang tinggi individualismenya, menghasilkan hak paten yang lebih banyak dan lebih tinggi dan lebih efisien dalam mengkonversi hasil-hasil penelitian menjadi output yang inovatif. Sebaliknya negaranegara yang penuh dengan ketidakpastian dan penghindaran menghasilkan hak paten yang lebih sedikit dan kurang bagus, dan kurang efisien dalam menggunakan biaya penelitian dan pengembangan.

Dengan demikian hasil penelitian terdahulu telah menunjukan hasil yang konsisten mengenai pengaruh budaya perusahaan terhadap kinerja perusahaan. Berdasarkan pembahasan tersebut di atas maka hipotesa kedua adalah sebagai berikut:

H2: Budaya perusahaan berpengaruh positif pada kinerja perusahaan.

Ukuran perusahaan (firm size) merupakan tingkat atau ukuran besarnya perusahaan. Indikator ukuran perusahaan dapat dijabarkan dalam berbagai ukuran seperti misalnya nilai aset dan jumlah modal. Berbagai penelitian telah membuktikan adanya hubungan antara ukuran perusahaan dengan laba perusahaan. Alexander et. al (2005) menyimpulkan dari hasil penelitiannya bahwa ada hubungan yang positif antara ukuran perusahaan dengan struktur modal. Amato et al (2007) melakukan penelitian mengenai pengaruh ukuran perusahaan terhadap tingkat 
laba perusahaan-perusahaan yang bergerak di bidang jasa keuangan dengan menggunakan berbagai definisi ukuran perusahaan. Hasilnya adalah terdapat hubungan yang positif antara ukuran perusahaan dengan laba perusahaan. Gaur (2007) menyimpulkan dari hasil penelitiannya bahwa ukuran perusahaan berpengaruh pada tingkat persediaan dan pertumbuhan penjualan.

Pertumbuhan penjualan pada akhirnya akan meningkatkan laba perusahaan. Mesut Dogan ( 2013) melakukan penelitian pada 200 perusahaan yang terdaftar di Istanbul Stock Exchange, dengan data antara tahun 2008 sampai dengan tahun 2011. Hasilnya adalah terdapat hubungan positif antara indikator-indikator ukuran dengan profitabilitas perusahaan. Jadi bila ukuran perusahaan meningkat maka kinerja juga akan meningkat. Chang et. al (2013) menunjukan dari hasil studi empirisnya bahwa terdapat hubungan antara ukuran perusahaan dengan kinerja keuangan. Abiodun (2013) melakukan penelitian mengenai hubungan antara ukuran perusahaan dengan kinerja perusahaan yang terdaftar pada Nigerian Stock Exchange, dengan menggunakan data panel tahun 2000-2009. Hasilnya adalah terdapat hubungan positif antara ukuran perusahaan, dalam ukuran jumlah aset dan penjualan, terhadap profitabilitas perusahaan pabrikasi di Nigeria. Kumas et. al (2014) melakukan penelitian pada pasar tenaga kerja Turki. Hasilnya dari studi empirisnya adalah terdapat hubungan antara ukuran perusahaan dengan kualifikasi pekerjaan. Jadi ada peran ukuran. Pomar (2016) menyimpulkan dari hasil penelitiannya bahwa enterpreneural orientation merupakan kondisi yang cukup untuk adanya kinerja pada perusahaanperusahaan jasa olah raga Spanyol yang kecil, bukan pada perusahaan-perusahaan besar.

Jadi berbagai penelitian di atas telah menunjukan pengaruh ukuran perusahaan pada kinerja perusahaan. Dengan demikian hipotesanya dapat ditetapkan sebagai berikut:

H3: Ukuran perusahaan berpengaruh positif pada kinerja perusahaan.

\section{Metode Penelitian}

Penelitian ini menggunakan metode penelitian kuantitatip. Pengolahan data dilakukan dengan menggunakan program eviews 9 .

Model penelitian kuantitatifnya dirumuskan sebagai berikut:

$\mathrm{Y}=\mathrm{a}+\mathrm{b} 1 \times 1+\mathrm{b} 2 \times 2+\mathrm{b} 3 \times 3+\mu$, dimana $\mathrm{Y}=$ kinerja perusahaan; $\mathrm{X} 1=$ penganggaran; $\mathrm{X} 2=$ budaya organisasi; dan $\mathrm{X} 3=$ ukuran perusahaan. 
Unit analisisnya adalah perusahaan. Populasinya adalah perusahaan-perusahaan publik yang terdaftar pada Bursa Efek Indoneia yang masuk klasifikasi LQ45. Pemilihan sampel dilakukan secara random terhadap perusahaan-perusahaan yang masuk kategori LQ45. Sebanyak 22 (dua puluh dua) perusahaan dijadikan sebagai sampel penelitian. Perusahaan-perusahaan tersebut merupakan perusahaan BUMN (Badan Usaha Milik Negara), perusahaan joint venture, dan perusahaan swasta nasional. Pengumpulan datanya dilakukan dari data sekunder, yang berasal dari website Bursa Efek Indonesia dan beberapa website pasar modal.

Pengukuran variabel-variabel dalam penelitian ini adalah sebagai berikut. Kinerja Perusahaan merupakan variable terikat. Proxy dari kinerja perusahaan yang digunakan dalam penelitian ini adalah laba perusahaan. Sumber datanya berasal dari Laporan Keuangan dan Laporan Tahunan (Annual Report). Proses penganggaran merupakan variable bebas. Proses penganggaran yang baik dilakukan dengan sistem PPBS (Planning Programming Budgeting System). Pengukuran penerapannya dengan menggunakan skala likert 1 sampai dengan 5. Unsur-unsur dari suatu proses penganggaran yang sangat baik adalah adanya visi, misi, tujuan, dan perencanaan; adanya programming; adanya proses penganggaran, yang disusun berdasarkan perencanaan dan programming; adanya implementasi anggaran; dan adanya pemantauan. Budaya Organisasi merupakan norma-norma, kepercayaan, atau persepsi bersama yang dianut oleh seluruh insan perusahaan. Budaya organisasi yang inovatif secara konseptual dan implementatif akan mendorong kinerja perusahaan. Pengukuran penerapannya dengan menggunakan skala likert 1 sampai dengan 5. Unsur-unsur budaya perusahaan yang sangat innovatif ditandai oleh adanya corporate values yang di adopsi perusahaan, adanya pedoman prosedur tersendiri untuk budaya perusahaan, adanya hubungan antara budaya perusahaan dengan corporate governance, adanya sosialisasi/internalisasi budaya perusahaan, dan adanya implementasi budaya perusahaan. Ukuran Perusahaan juga merupakan salah satu variable bebas. Proxy dari ukuran perusahaan adalah laba. Laba merupakan suatu konsep dengan indikator laba tahun berjalan. Angkanya diperoleh dari laporan keuangan.

Pada dasarnya analisis data yang dilakukan akan meliputi uji normalitas dan uji regresi. Uji normalitas data, untuk menentukan apakah datanya normal atau tidak sehingga layak diregress dan dijadikan dasar pengambilan simpulan dan keputusan. Pengolahan akan dilakukan dengan program eviews 9. Indikator normalitas data terutama berdasarkan nilai Jarqua Berra. Nilai absolut Jarque-Bera menjadi ukuran penyimpangan distribusi dari normal. Dalam aplikasinya 
nilai Jarque-Bera dibandingkan dengan nilai chi-square tabel pada derajat kebebasan 2. Jadi ambang batas atas nilai Jarque Bera adalah 2. Bila nilainya di atas 2 maka berarti penyimpangan distribusi tidak normal. Uji multikolinearitas untuk menentukan adanya hubungan antara variabel independen Petunjuknya terutama dengan indikator atau nilai Durbin Watson Statistics. Adanya multikolinearitas juga bisa dideteksi dengan Variance Inflation Factor (VIF). Bila nilai Centered VIF <10 maka berarti tidak ada multikor. Uji heteroskedastisitas untuk mengetahui adanya probable density of $\mu i$. Petunjuknya dengan indikator nilai Durbin Watson, Uji White, atau BPG test. Uji regresi untuk mengetahui besar perubahan variabel $\mathrm{Y}$ yang dapat dijelaskan oleh variabel X (goodness of fit). Uji ini terutama ditunjukan dengan indikator R2. Uji F untuk mengetahui pengaruh secara keseluruhan (simultan) variabel independen terhadap variabel dependennya (dengan indikator signifikansi F). Uji t untuk mengetahui pengaruh parsial satu variabel independen terhadap variabel dependennya (dengan indikator signifikansi t).

\section{Hasil Penelitian dan Pembahasan}

Sebelum dilakukan uji kausalitas antara variabel bebas dengan variabel terikat, maka dilakukan uji asumsi klasik terhadap distribusi sampel data penelitian yang telah dikumpulkan. Pengujian dilakukan dengan program eviews 9.

Uji normalitas terhadap distribusi sampel data penelitian menunjukan hasil sebagai berikut:

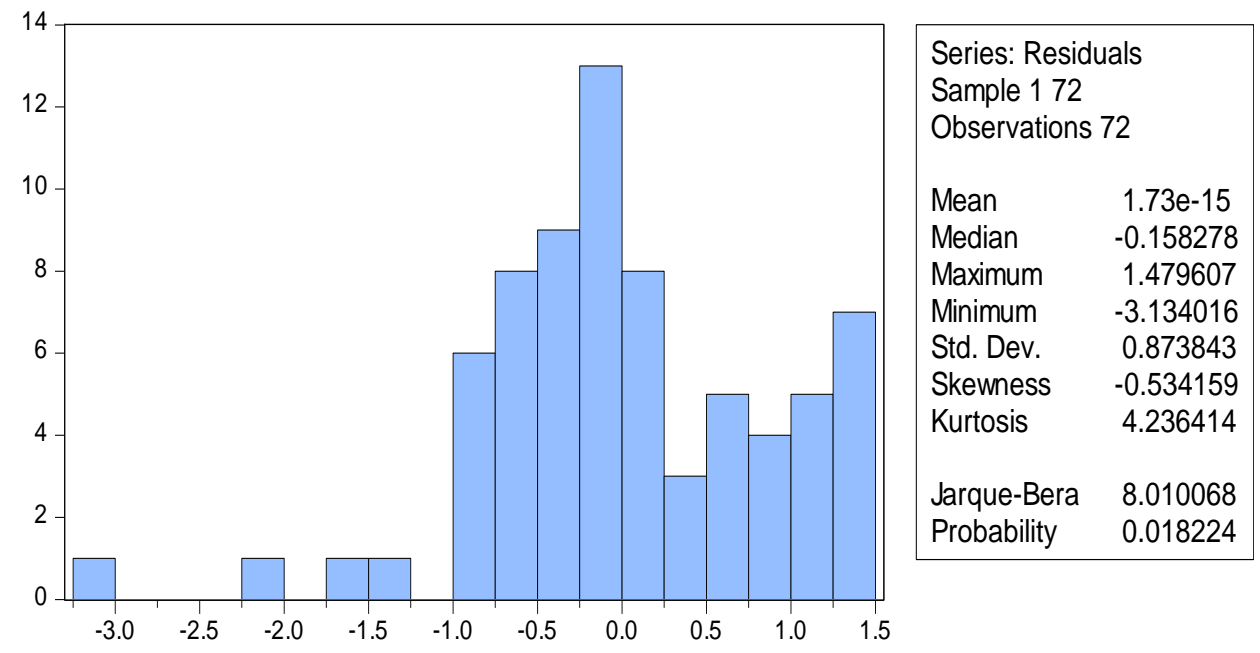

(Sumber: data diolah) 
Dari hasil uji normalitas di atas terlihat bahwa indikator kecondongan adalah -0,534159. Masih di bawah 3. Berarti distribusi sampel tidak terlalu condong. Indikator kurtosis 4,23. Berarti distribusi sampel agak mancung. Ini mungkin disebabkan adanya beberapa sampel dengan karakteristik khusus. Namun kemancungan itu belum terlalu mancung. Karena distribusi agak mancung, maka indikator Jarqua Bera menjadi 8 (lebih besar dari 2).

Berdasarkan hasil uji heterokedastisitas dengan Breusch Pagan Godfrey (BPG) yang dilakukan dengan program eviews 9 diperoleh prob chi square sebesar 0,4048 (lebih besar dari 0,05). Tidak signifikan. Berarti distribusi sampel tidak mengalami heteroskedastisitas. Pada table hasil regresi berikut juga dapat dilihat indikator heterokedastisitas.

\begin{tabular}{|c|c|c|c|c|}
\hline \multicolumn{3}{|c|}{ Dependent Variable: LABA } & & \\
\hline \multicolumn{3}{|c|}{ Method: Least Squares } & & \\
\hline \multicolumn{3}{|c|}{ Date: 03/18/18 Time: $20: 49$} & & \\
\hline \multicolumn{2}{|l|}{ Sample: 172} & & & \\
\hline \multicolumn{3}{|c|}{ Included observations: 72} & & \\
\hline Variable & Coefficient & Std. Error & t-Statistic & Prob. \\
\hline $\mathrm{C}$ & 0.528219 & 1.283405 & 0.411576 & 0.6819 \\
\hline BUDGETING & -0.710921 & 0.148420 & -4.789922 & 0.0000 \\
\hline ASET & 0.826979 & 0.116417 & 7.103561 & 0.0000 \\
\hline BUDAYA & 0.413352 & 0.103965 & 3.975891 & 0.0002 \\
\hline R-squared & 0.551075 & \multicolumn{2}{|c|}{ Mean dependent var } & 7.621835 \\
\hline Adjusted R-squared & 0.531270 & \multicolumn{2}{|c|}{ S.D. dependent var } & 1.304207 \\
\hline S.E. of regression & 0.892910 & \multicolumn{2}{|c|}{ Akaike info criterion } & 2.665292 \\
\hline Sum squared resid & 54.21565 & \multicolumn{2}{|c|}{ Schwarz criterion } & 2.791773 \\
\hline Log likelihood & -91.95050 & \multicolumn{2}{|c|}{ Hannan-Quinn criter. } & 2.715644 \\
\hline F-statistic & 27.82437 & \multicolumn{2}{|c|}{ Durbin-Watson stat } & 1.343229 \\
\hline Prob(F-statistic) & 0.000000 & & & \\
\hline
\end{tabular}

(Sumber: data diolah) 
Pada tabel di atas juga dapat dilihat bahwa indikator durbin watson adalah 1,34. Lebih kecil dari 2 dan lebih besar dari -2. Ini juga merupakan petunjuk tidak adanya heterokedastisitas pada distribusi sampel. Indikator DW yang lebih kecil dari 4 dan lebih besar dari 0 juga menunjukan tidak adanya serial correlation di dalam model penelitian.

Dari data diolah menunjukan nilai Variance Inflation Factor (VIF) untuk seluruh variabel bebas lebih kecil dari $10(1,09 ; 1,04$; dan 1,09).. Ini menunjukan tidak adanya multikolinearitas di dalam model penelitian. Pada table regresi di atas juga dapat dilihat bahwa adjusted R squared 53 $\%$. Ini merupakan model penelitian yang sangat fit karena $53 \%$ variasi perubahan dalam variabel terikat yang dapat dijelaskan oleh variabel bebas.

Pada table hasil regresi di atas dapat dilihat uji simultan menunjukan prob ( $\mathrm{F}$ statistik) 0,00 $(<0,05)$. Artinya variabel sistem penganggaran, budaya organisasi, dan ukuran perusahaan secara simultan berpengaruh signifikan pada kinerja perusahaan. Berarti penelitian valid untuk dilanjutkan. Prob t statistic 0,00 $(<0,05)$. Signifikan. Artinya sistem penganggaran berpengaruh signifikan pada kinerja perusahaan. Namun ternyata tandanya atau koefisiennya menjadi negatif. Artinya hubungan antara variabel proses penganggaran dengan kinerja perusahaan bertolak belakang. Prob t statistic $0,00 \quad(<0,05)$. Signifikan. Artinya variabel budaya organisasi berpengaruh signifikan pada peningkatan kinerja perusahaan. Prob t statistic $0,00(<0,05)$. Signifikan. Artinya variabel ukuran perusahaan berpengaruh signifikan pada peningkatan kinerja perusahaan.

Hasil uji F menunjukan bahwa variabel sistem penganggaran, variabel budaya perusahaan, dan variabel ukuran perusahaan secara simultan berpengaruh pada kinerja perusahaan. Dan besar $R-$ squared mencapai $55 \%$. Koefisien regresi yang bagus adalah bila lebih besar dari $50 \%$. Pada kondisi ini maka $55 \%$ variasi perubahan dalam variabel terikat dapat dijelaskan oleh perubahan variabel bebas. Suatu model penelitian yang cukup fit sehingga dapat digunakan untuk dasar pengambilan keputusan.

Dari hasil uji t, Prob t statistic variabel sistem penganggaran 0,00 $(<0,05)$. Signifikan. Artinya sistem penganggaran berpengaruh signifikan pada kinerja perusahaan. Namun ternyata tandanya atau koefisiennya menjadi negatif. Artinya hubungan antara proses penganggaran dengan kinerja perusahaan menjadi bertolak belakang. Kondisi di unit analisis ini menunjukan bahwa sistem penganggaran tidak mendukung peningkatan kinerja perusahaan, justru semakin baik sistem 
penganggaran maka laba semakin menurun. Hal ini mungkin karena pada sebagian besar data sampel penggunaan anggaran hanya formalitas saja sehingga tidak berpengaruh pada peningkatan kinerja. Kegiatan penyusunan anggaran justru menjadi kegiatan yang memberi pengaruh pada penurunan laba perusahaan. Pada salah satu perusahaan yang menjadi sampel telah disebutkan bahwa tanggungjawab utama Direktur Utama adalah 1. Mengarahkan penyusunan strategi dan rencana kerja Perusahaan baik Rencana jangka Panjang (corporate plan), Rencana jangka Menengah (Rencana Bisnis Bank/RBB), Rencana kerja dan anggaran Perusahaan (RkaP) serta perubahannya sebagai pedoman dalam mencapai target kinerja Perusahaan 2. Mengarahkan pengembangan dan pencapaian target Perusahaan. 3. Memberikan laporan pertanggungjawaban dan penjelasan atas pengurusan Perusahaan. 4. Mengarahkan pelaksanaan tindak lanjut audit baik internal maupun eksternal. 5. Menjalankan fungsi pembinaan terhadap anggota direksi untuk memperlancar pencapaian target kinerja perusahaan. Tanggungjawab Direksi tersebut telah mencerminkan tugas penerapan proses penganggaran yang baik. Tetapi pada beberapa sampel lainnya mungkin sistem penganggaran dan penerapannya tidak dilakukan dengan baik. Dengan demikian hipotesa 1 tidak terbukti.

Fenomena ini mendukung penelitian-penelitian terdahulu yang simpulannya menunjukan tidak adanya hubungan antara sistem penganggaran dengan kinerja perusahaan. Dari penelitian Lidia (2015) ternyata proses penganggaran hanya mendukung $27 \%$ dari peningkatan kinerja pada satuan-satuan ekonomi di negara Rumania. Messer (2017) menyimpulkan bahwa isi anggaran dianggap cuma kebohongan. Anggaran dianggap hanya terkaan terhadap masa yang akan datang. Rencana pengeluaran hanya dimaksudkan untuk mengelola ketidakpastian. Dengan kata lain Messer berpendapat bahwa anggaran sengaja disalah sajikan, sehingga isinya cuma kebohongan.

Prob t statistic variabel budaya perusahaan adalah $0,00(<0,05)$. Artinya variabel budaya organisasi berpengaruh signifikan pada peningkatan kinerja perusahaan. Hal ini menunjukan bahwa budaya organisasi yang dibangun atau terbangun pada sebagian besar data sampel telah berfungsi untuk mengarahkan dan memotivasi pencapaian target kinerja perusahaan. Setiap perusahaan pada data sampel memiliki keyakinan yang tidak tepat sama tentang nilai-nilai perusahaan mereka. Organisasi berisi kumpulan orang-orang dan setiap kumpulan orang-orang memiliki keyakinan tersendiri tentang nilai-nilai inti (core values) pada organisasi mereka. PT Wijaya Karya misalnya (Annual Report 2016, halaman 81) menyatakan bahwa budaya perusahaan mereka adalah experience, teamwork, professionalism, dan integrity . Pada beberapa 
perusahaan lain pada data sampel terdapat penggambaran yang berbeda-beda tentang budaya perusahaan mereka. Dengan demikian hipotesa 2 terbukti. Chen, Podolski, dan Veeraraghavan (2017) juga telah membuktikan dalam hasil penelitiannya bahwa budaya nasional berpengaruh terhadap inovasi perusahaan.

Prob t statistic untuk variabel ukuran perusahaan adalah $0,00(<0,05)$. Artinya variabel ukuran perusahaan berpengaruh signifikan pada peningkatan kinerja perusahaan. Hal ini menunjukan bahwa pada sebagian besar perusahaan ukuran perusahaan menjadi modal penting dalam mendorong kinerja perusahaan. Bila dilakukan regresi langsung pengaruh ukuran perusahaan pada laba perusahaan diperoleh prob t-statistic 0,00 . Artinya sangat signifikan, dengan $\mathrm{R}$ squared mencapai $54 \%$. Terbukti bahwa ukuran perusahaan berpengaruh positif signifikan pada kinerja perusahaan, dengan R squared mencapai $54 \%$. Artinya bahwa sebanyak $54 \%$ variasi perubahan dalam variable terikat yang dapat dijelaskan oleh perubahan dalam variabel bebas. Jadi terbukti bahwa semakin besar perusahaan maka akan semakin besar kemampuannya untuk mencapai kinerja. Semakin besar perusahaan maka semakin besar sumber daya yang dimilikinya dan semakin luas hubungan yang dimilikinya. Penelitian-penelitian terdahulu juga telah membuktikan pengaruh positif ukuran perusahaan pada kinerja perusahaan. Abiodun (2013) misalnya telah melakukan penelitian mengenai hubungan antara ukuran perusahaan dengan kinerja perusahaan yang terdaftar pada Nigerian Stock Exchange, dengan menggunakan sampel berupa data panel tahun 2000-2009. Hasil penelitiannya menunjukan bahwa terdapat hubungan positif antara ukuran perusahaan, dalam ukuran jumlah aset dan penjualan, terhadap profitabilitas perusahaan pabrikasi di Nigeria.

\section{E. Simpulan dan saran}

Proses penganggaran merupakan kegiatan manajemen yang sangat penting. Proses penganggaran dapat mendorong tercapainya tujuan-tujuan perusahaan. Namun pada perusahaan-perusahaan tertentu yang telah menggunakan proses pengganggaran yang baik rentabilitasnya kurang memuaskan. Fenomena ini menimbulkan pertanyaan apakah proses penganggaran berpengaruh positif pada kinerja perusahaan. Juga terdapat variabilitas pada hasil-hasil penelitian terdahulu mengenai pengaruh proses penganggaran, budaya perusahaan, dan ukuran perusahaan pada kinerja perusahaan. 
Tujuan dari penelitian ini adalah untuk mempelajari bagaimana pengaruh variabel-variabel sistem penggaran, budaya perusahaan, dan ukuran perusahaan tersebut pada perusahaan-perusahaan yang terdaftar pada Bursa Efek Indonesia yang masuk kategori LQ 45.

Sebanyak 22 (dua) perusahaan dijadikan sebagai sampel, dengan data time series masing-masing sebanyak 7 (tujuh) tahun. Pengolahan datanya menggunakan metode kuantitatif.

Hasil penelitian menunjukan bahwa budaya organisasi dan ukuran perusahaan secara individual berpengaruh positif signifikan pada kinerja perusahaan. Sedangkan proses penganggaran secara signifikan berpengaruh pada kinerja perusahaan, tapi dengan pengaruh yang berlawanan. Proses penganggaran malah berpengaruh negatif signifikan pada kinerja perusahaan. Dengan demikian hasil penelitian mengenai proses penganggaran tidak membuktikan bahwa proses penganggaran akan mengurangi agency problem antara pemilik perusahaan dengan manajer sebagai agen perusahaan. Sedangkan adanya budaya perusahaan terbukti mendukung peningkatan kinerja perusahaan dan dengan demikian mengurangi permasalahan keagenan antara pemilik dengan manajer.

Berdasarkan simpulan tersebut di atas maka dapat disarankan hal-hal sebagai berikut:

1. Sistem penganggaran agar benar-benar digunakan dalam proses pengendalian sehingga berpengaruh pada peningkatan kinerja, bukan sebaliknya.

2. Budaya organisasi yang telah dikembangkan agar lebih dikembangkan lagi, minimal dipertahankan.

3. Perusahaan-perusahaan agar selalu berusaha meningkatkan modalnya sehingga besarannya semakin menigkat. Semakin besar perusahaan akan semakin besar kemampuannya untuk dapat mencapai tujuan-tujuannya.

4. Para peneliti selanjutnya dapat melakukan penelitian mengenai faktor-faktor lain yang mempengaruhi kinerja perusahaan yang terdaftar di Bursa Efek Indonesia, sehingga hasil penelitian keseluruhan dapat digunakan untuk membina perusahaan-perusahaan yang terdaftar pada Bursa Efek Indonesia.

\section{Daftar Referensi}

\section{Buku:}

Ghozali, Imam, Ratmono, Dwi. Analisis Multivariat dan Ekonometrika: Teori, Konsep, dan Aplikasi Dengan Eviews 8. Universitas Diponegoro Semarang, 2013. 


\section{Jurnal Penelitian:}

Abata, Matthew A. Participative Budgeting and Managerial Performance in the Nigerian Food Products Sector. Global Journal of Contemporary Research in Accounting, Auditing and Business Ethics (GJCRA), 2014 Vol: 1 Issue 3.

Amato, Louis H. Burson, Charlotte Timothy E. The Effects Of Firm Size On Profit Rates In The Financial Services. Journal of Economics and Economic Education Research, Volume 8, Number 1, 2007.

Altındağa , Erkut; Kösedağı, Yeliz; The Relationship between Emotional Intelligence of Managers, Innovative Corporate Culture and Employee Performance. Elsevier, 2015.

Astrah, Syazliana; Idrisa, Mohammad; Abdul Wahabb, Rabiah; Jaaparc, Aiini. Corporate Cultures Integration and Organizational Performance: A Conceptual Model on the Performance of Acquiring Companies. Elsevier, 2014.

Brenes, Esteban R; Ciravegna, Luciano; Woodside, Arch G. Constructing Useful Models of Firms' Heterogeneities in Implemented Strategies and Performance Outcomes. The Elsevier Ltd., 2016.

Bruun, Mikkel; Laumet, Pascal. Managing asset maintenance needs and reaching performance goals within budgets. Elsevier, 2016.

Chang, Chia Lin. Hsu, Hui Kuang. McAleer, Michael. Is Small Beautiful? Size Effects of Volatility Spillovers for Firm Performance and Exchange Rates In Tourism. North American Journal of Finance and Economics, 2013.

Chen, Yang yang; Podolski, Edward J; Veeraraghavan, Maldhu. National culture and corporate innovation. Elsevier, 2017.

D Andrea, Vincenzo; Bettega, Mela; Poderi, Geacomo; Cappacioli, Andrea. Exploring participatory energy budgeting as a policy instrument to foster energy justice. Elsevier, 2017.

Derfuss, Klaus. Reconsidering the participative budgeting-performance relation: a metaanalysis regarding the impact of level of analysis, sample selection, measurement, and industry influences. The British Accounting Review, 2015.

Dogan, Mesut. Does Firm Size Affect The Firm Profitability? Evidence From Turkey. Research Journal of Finance and Accounting, Vol. 4, No. 4, 2013 
Gaur1, Vishal. , Saravanan Kesavan. The Effects of Firm Size and Sales Growth Rate on Inventory Turnover Performance in the U.S. Retail Sector. 1 Johnson Graduate School of Management, Cornell University, 2007.

Gillen Kirch, Robert M.; Arnold, Markus C. Using Negotiated Budget for Planning and Performance Evaluation: An Experimental Study. Elsevier, 2016.

Giuberti, Ana Carolina. Budget institutions and fiscal performance of the Brazilian Federal Government. 2015.

Idrisa, Syazliana Astrah Mohd; Wahabb, Rabiah Abdul ; Jaapar, Aini. Corporate Cultures Integration and Organizational Performance: A Conceptual Model on the Performance of Acquiring Companies. Elsevier Ltd., 2015.

Imam Syafii, Lukman; Thoyib, Armanu; Nimran, Umar; Djumahir. The Role of Corporate Culture and Employee Motivation as a Mediating Variable of Leadership Style Related with the Employee Performance (Studies in Perum Perhutani). Elsevier, 2015.

Jeremias, Johhny; Yigit, Fatih. Budgetary Participation in Turkey: The Effects of Information Asymmetry, Goal Commitment, and Role Ambiguity on Job Satisfaction and Performance. Journal of International Accounting Research, American Accounting Association Vol. 12, 2013.

Johannson, Tobias. Siverbo, Sven . The appropriateness of tight budget control in public sector organizations facing budget turbulence. Elsevier, 2014.

Kumaşa, Handan. Caglarb, Atalay. Karalpc, Hacer Simay. Firm Size and Labour Market Segmentation Theory: Evidence from Turkish Micro Data. 10th International Strategic Management Conference, 2014.

Mei, Ling Yang; Andrew Ming, Long Wang; Kuo, Chih Cheng. The Impact of Quality of IS Information and Budget Slack on Innovation Performance. Elsevier Ltd., 2009.

Kuo, Chih Cheng; Wang, Andro Ming Long. Cheng, Kuo Chih. The Impact of Quality of IS Information on budget slack of performance. Elsevier, 2009.

Lestira, Magnaz; Purnamasari, Pupung; Hariyanti, Widi. Pluriform motivation as antecedent and its relationships to budgeting participation and managerial performance (Empirical Study on Manufacturing Companies listed on Indonesian Stock Exchange). Elsevier, 2015. 
Lidia, Tanase Gabriela. An analysis of the existence of a link between budgets and performance in economic entities. Elsevier, 2015.

Linton, Gabriel; Kask, Johan. Configurations of Enterpreneurial Orientation and Competitive Strategy for High Performance. The Elsevier, 2016.

Messer, Ron. Budgets and Other Lies: Evidence of Bias in Financial Planning. Elsevier, 2017.

Macinati, Manuela S. Rizzo, Marco G. Budget goal commitment, clinical managers' use of budget information and performance. Elsevier, 2014.

Mattila, Anna S.; Xinyuan, Zhao; Jianping, Peng. Improving service management in budget hotels. Elsevier, 2015.

Mills, Zhachary; Grogoli, Fransesco; Verhoeven, Marijn; Vlaicu, Razvan. Multiyears budget and fiscal performance: panel data evidence. Journal of Public Economics, 2014.

Pomar, Juan Nunes. Gasco, Vicente Prado. Sanz, Vicente Ano. Hervas, Josep, Crespo. Moreno, Ferran Callabuig. Does Size Matter? Entrepreneurial Orientation and Performance in Spanish Sport Firms. Journal of Business Research, 2016.

Siyang, Gao; Hui, Xiao; Enlu, Zhou; Wei wei, Chen. Robust ranking and selection with optimal computing budget allocation. Elsevier, 2017.

Silva, Rosario; Gerwea, Oksana; Becerrab, Manuel. Corporate brand and hotel performance: A resource-based perspective. Elsevier, 2017.

Strese, Steffen; Adam, Daniel R.; Flatten, Tessa C.; Brettel, Malte. Corporate Culture and Absortive Capacity. Elsevier, 2016.

Wallace, Sandra; Clarkson, Peter; King, Robbyn. Budgeting practices and performance in small healthcare business. Elsevier, 2010.

Wijethilake, Chaminda. Proactive Sustainability Strategy and Corporate Sustainability Performance: The Mediating Effect of Sustainability Control Systems. Elsevier Ltd., 2017.

Yingce ,Xia; Tao, Qin; Wenkui, Ding; Haifang, Li; Xudong, Zhang; Nenghai, Yu; Tie, Yan Liu. Finite Budget Analysis of Multi-armed Bandit Problems. Elsevier, 2016.

Yisau Abiodun, Babalola. The Effect of Firm Size on Firms Profitability in Nigeria. Journal of Economics and Sustainable Development Vol.4, No.5, 2013

\section{Website:}


www.idx.co.id 